\title{
Late Quaternary Sequence Stratigraphy in Kyeonggi Bay, Mid-eastern Yellow Sea
}

\author{
Yi Kyun Kwon* \\ Petroleum and Marine Resource Division, Korea Institute of Geoscience and Mineral Resources, \\ Daejeon 305-350, Korea
}

\section{황해 중동부 경기만의 후기 제4기 순차층서 연구 \\ 권 이 균* \\ 한국지질자원연구원 석유해저연구본부, 305-350, 대전광역시 유성구 과학로 124}

\begin{abstract}
The Yellow Sea has sensitively responded to high-amplitude sea-level fluctuations during the late Quaternary. The repeated inundation and exposure have produced distinct transgression-regression successions with extensive exposure surfaces in Kyeonggi Bay. The late Quaternary strata consist of four seismic stratigraphic units, considered as depositional sequences (DS-1, DS-2, DS-3, and DS-4). DS-1 was interpreted as ridge-forming sediments of tidal-flat and estuarine channel-fill facies, formed during the Holocene highstand. DS-2 consists of shallow-marine facies in offshore area, which was formed during the regression of Marine Isotope Stage (MIS)-3 period. DS-3 comprises the lower transgressive facies and the upper highstand tidal-flat facies in proximal ridges and forced regression facies in distal ridges and offshore area. The lowermost DS-4 rests on acoustic basement rocks, considered as the shallow-marine and shelf deposits formed before the MIS-6 lowstand. This study suggests six depositional stages. During the first stage-A, MIS-6 lowstand, the Yellow Sea shelf was subaerially exposed with intensive fluvial incision and weathering. The subsequent rapid and high amplitude rise of sea level in stage-B until the MIS-5e highstand produced transgressive deposits in the lowermost part of the MIS-5 sequence, and the successive regression during the MIS-5d to $-5 \mathrm{a}$ and the MIS-4 lowstand formed the upperpart of the MIS-5 sequence in stage-C. During the stage-D, from the MIS-4 lowstand to MIS-3c highstand period, the transgressive MIS-3 sequence formed in a subtidal environment characterized by repetitive fluvial incision and channel-fill deposition in exposed area. The subsequent sea-level fall culminating the last glacial maximum (Stage-E) made shallow-marine regressive deposits of MIS-3 sequence in offshore distal area, whereas it formed fluvial channel-fills and floodplain deposits in the proximal area. After the last glacial maximum, the overall Yellow Sea shelf was inundated by the Holocene transgression and highstand (Stage-F), forming the Holocene transgressive shelf sands and tidal ridges.
\end{abstract}

Keywords: Kyeonggi Bay, sequence stratigraphy, Yellow Sea, sea-level curve, late quaternary sequence model

요 약: 황해 경기만은 제4기에 반복된 해침과 해퇴로 4개의 해침-해퇴 퇴적체(DS-1, DS-2, DS-3, DS-4)를 형성하였다. 본 연구는 황해 경기만 퇴적체의 형성을 6개 퇴적단계로 나누어 설명한다. A 단계는 MIS-6 저해수면 시기로서 큰 규 모의 해수면 하강으로 인해 대부분의 지역이 대기에 노출되고 광범위한 하도 침식 및 풍화작용의 영향을 받았다. 이어 지는 B 단계는 MIS-5e 까지 빠른 해수면 상승과정에서 MIS-5 시퀀스의 하부 해침퇴적체가 형성되었고, 다음에 이어지 는 MIS-5d부터 MIS-4 저해수면 시기까지의 C 단계에서는 MIS-5 시퀀스의 상부인 해퇴퇴적체가 만들어졌다. 다음의 D 단계는 MIS-4 저해수면 시기부터 MIS-3c 고해수면 시기까지로 하도 침식 및 하도 충전 구조로 이루어진 MIS-3 해 침 퇴적체가 형성되었다. 다음의 $\mathrm{E}$ 단계에서는 LGM 시기까지 계속적인 해수면 하강이 있었고 외해쪽에서는 천해 기 원의 MIS-3 해퇴퇴적체가 만들어진 반면에, 내륙쪽에서는 노출된 환경에서 하도 충전 퇴적체나 범람원 퇴적체가 형성 되었다. 마지막 단계인 $\mathrm{F}$ 단계는 황해 전체적으로 홀로세 해침이 발생하였고, 이 시기에 외해쪽에서는 대륙붕 사질 퇴 적체와 조석사주 퇴적체가 형성되어 고해수면 시기인 현재까지 퇴적이 일어나고 있다.

*Corresponding author: kyk70@kigam.re.kr

Tel: $+82-42-868-3394$

Fax: $+82-42-868-3417$ 
주요어: 경기만, 순차층서, 황해, 해수면 변동, 제4기 순차층 모델

\section{Introduction}

A very shallow epicontinental sea has sensitively responded to high-amplitude sea-level fluctuations during the late Quaternary (Broecker et al., 1988; Alexander et al., 1991; Qin and Zhao, 1991; Ergin, 1996; Berné et al., 2002; Liu et al., 2004). The repeated inundation and exposure produced typical transgression-regression successions with extensive exposure surfaces in shelf areas (Posamentier et al., 1992; Hardenbol et al., 1998; Suter, 2006). During the glacial periods, most shelf areas were subaerially exposed due to large-scale sea level drop, covered by oxidized coastal or fluvial coarse-grained deposits (Plint, 1988; Posamentier et al., 1992; Plint and Nummedal, 2000; Suter, 2006). The successive rise of sea level during the interglacial periods caused broad inundation and landward retreat of coastlines, forming transgressive estuarine and the following highstand deltaic successions (Penland et al., 1988; Kim et al., 1999; Berné et al., 2002; Choi and Dalrymple, 2004; Liu et al., 2004). The records of sea level fluctuations and response of sedimentary system are well preserved in the shallow shelf sequences.

The Yellow Sea is an epicontinental sea surrounded by eastern coasts of China, Bohai Bay, and western coasts of the Korean Peninsula (Chough et al., 2000; Chough et al., 2004). Kyeonggi Bay is located in the mid-eastern margin of the Yellow Sea (Fig. 1). The shallow strata of the bay are characterized by successive stacking of fluvial, estuarine, and submerged tidalridge sequences, strongly influenced by macro-scale tidal processes (Frey et al., 1989; Alexander et al., 1991; Jin and Chough, 1998; Li et al., 2000; Berné et al., 2002). The stratigraphic works in tidal or fluvial deposits have concentrated on identifying HolocenePleistocene boundary and on reconstructing the Holocene sea-level curve (Choi, 2001; Lim and Park, 2003; Lim et al., 2003; Choi, 2005). On the other hand, the works in offshore or tidal ridges have been concerned with formative processes of tidal ridges and Holocene sequence stratigraphy (Park and Yoo, 1988; Park et al., 1990; Lee and Yoon, 1997; Jin and Chough, 1998; Jin and Chough, 2002; KIGAM, 2004).

However, the pre-Holocene stratigraphy has not been unveiled because the architectural structure of the late Pleistocene strata in the bay is much complicated and the chronostratigraphy for the strata is not reliable because of a window of radiocarbon age dating. Recently, voluminous geophysical and geological data have been obtained and compiled in order to establish the stratigraphy in the bay (KIGAM, 2004). This study uses deep-drilled NYSDP-101 and YSDP-106/ 107 cores and the supplementary deep-drilled sediment cores for analyses on lithology and chronology. The geophysical data include multi-channel air-gun, sparker $(0.3-1 \mathrm{kHz})$, and chirp $(0.5-12 \mathrm{kHz})$ seismic profiles. Based on the integrating analyses on seismic and core sediment data, this study suggests a new pre-Holocene stratigraphic scheme and a sequence model for sedimentary response to the late Quaternary highamplitude sea-level fluctuations.

\section{Geologic Setting}

The Yellow Sea is a tide-dominated, shallow epicontinental sea, surrounded by the landmass of China and Korea Peninsula, that has been assumed to be tectonically stable since the Late Miocene (Fig. 1; Chough et al., 2000; Chough et al., 2004). The eastern Yellow Sea, bordered by numerous coastal embayments and estuaries, is a macrotidal environment with comparatively few and minor fluvial sediment sources, whereas the western part is a mesotidal environment with a large sediment input from the Huanghe and Yangtze rivers (Lim and Park, 2003). The Yellow Sea has a flat and broad seafloor with an average water depth of $55 \mathrm{~m}$, less than $100 \mathrm{~m}$ in water depth (Chough et al., 2000). Except for the deep depression 


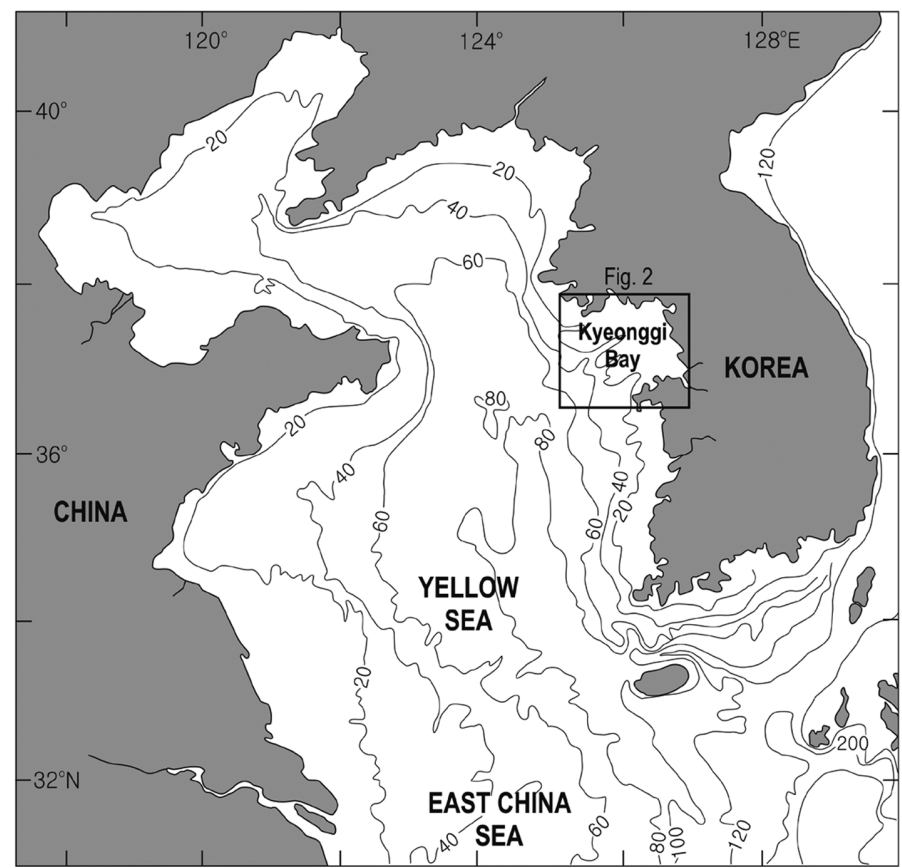

Fig. 1. Location and bathmetry map of Kyeonggi Bay in the mid-eastern Yellow Sea (modified from Chough et al., 2004).

around Jeju Island, the sea floor deepens toward the north-south trending axis that lies in the eastern part of the sea (Fig. 1; Chough et al., 2004).

The Yellow Sea shelf was subaerially exposed during the Marine Isotope Stage (here after MIS)-6 lowstand period (ca. 160-140 ka). During the MIS-5 (ca. 130-70 ka), a high amplitude sea-level rise (more than $120 \mathrm{~m}$ ) with several fluctuations made most of the shelf area submerged. The following MIS-4 (ca. $70-55 \mathrm{ka}$ ) is characterized by subaerial exposure and fluvial incision of large area of the shelf due to lowering of about $80-100 \mathrm{~m}$ below the present sea level. After a short and slight rise of sea level during MIS-3c (ca. 55-50 ka), the sea-level drop resumed and most of the shelf area was entirely re-exposed subaerially until the last glacial maximum (here after LGM, ca. 18-16 ka). In the central part of the sea, marine transgression initiated at about 12-11 ka (Wang et al., 1985; Kim and Kennett, 1998; Chough et al., 2004) and sea level reached the present position at about 6 ka (Chough et al., 2000).

The study area is located in Kyeonggi Bay, the largest macrotidal embayment along the western coast of Korea (Fig. 1). Unlike the rest of the Korean coast, it receives substantial sediment input from the Han River, leading to the accumulation of up to $60 \mathrm{~m}$ of the late Quaternary tidal deposits (Fig. 2; Jin, 2001; Choi and Dalrymple, 2004). The subtidal area is dominated by large four tidal ridges (bars) and intervening troughs, the inner parts of which are highly dissected by smaller tidal channels (Fig. 2; Choi and Dalrymple, 2004). The tidal ridges are main sediment bodies that project southwestward from Kyeonggi Bay into the Yellow Sea (Fig. 2A). The previous deep-drilled cores (YSDP-107 and NYSDP101) of the ridge have shown that there is as much as $60 \mathrm{~m}$ of tidal deposits overlying lowstand fluvial sediments, which in turn rest on basement bedrock.

This study recognizes four depositional settings of tidal ridges in Keonggi Bay: offshore, distal tidal ridge, proximal tidal ridge, and tidal flats (Fig. 2B). Offshore Kyeonggi Bay consists mainly of a few meter thick, sand-prone facies formed during the Holocene transgression and the underlying late Pleistocene mud or sandy mud (Shinn et al., 2007). The tidal ridges in Kyeonggi Bay can be divided into 

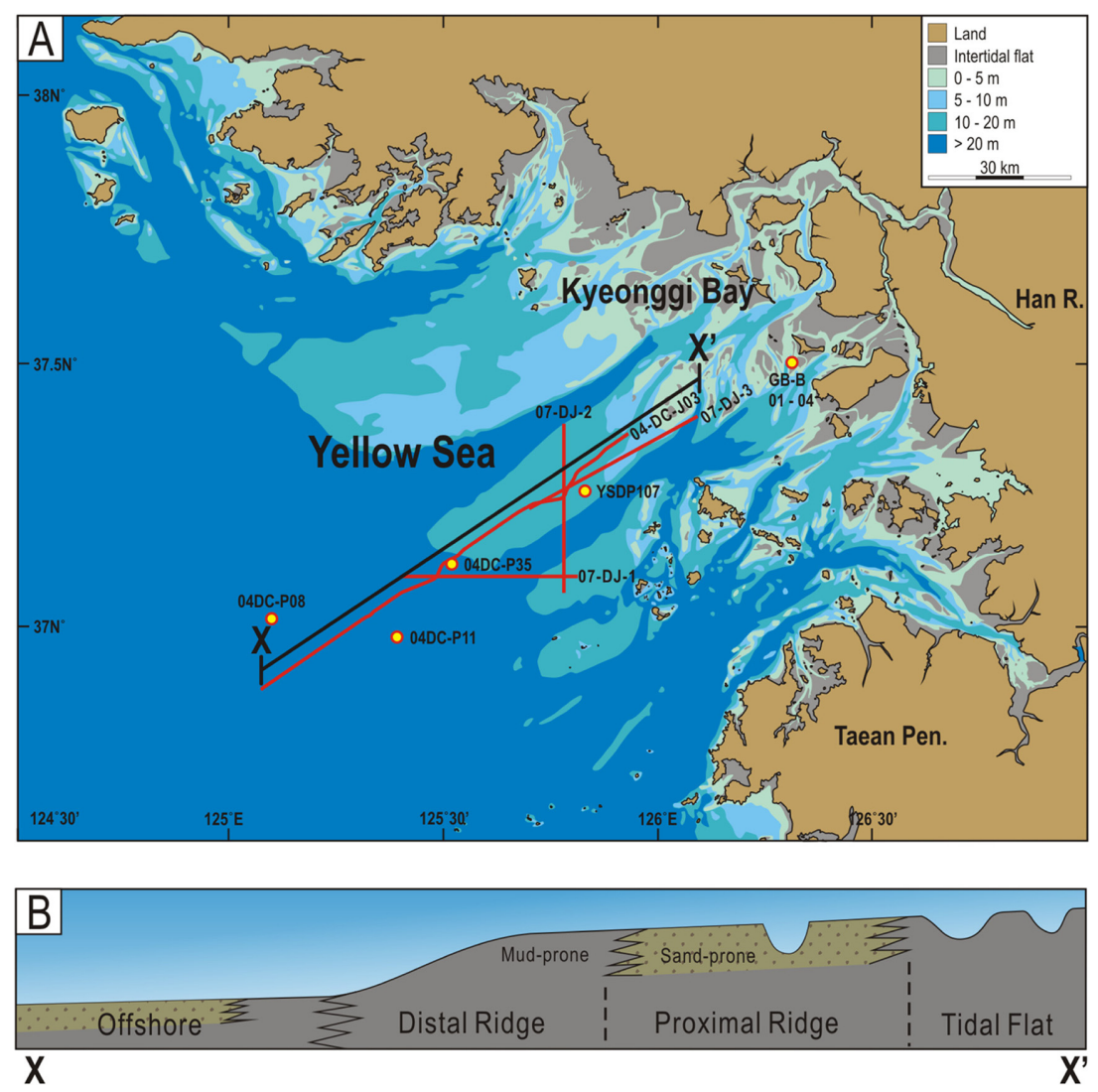

Fig. 2. Geological location of Kyeonggi Bay (modified from KIGAM, 2004). (A) Bathymetry map showing locations of seismic profiles (red line) and cores (yellow circle) in the study area. (B) Cross section of tidal sand ridge (X-X').

mud-dominated distal and sand-dominated proximal ridges (Fig. 2B). The tidal ridges are connected landward to broad tidal flats attached to numerous islands and coasts in Kyeonggi Bay.

\section{Materials and Methods}

Multi-channel seismic profiles were obtained in the offshore part of Kyeonggi Bay with the $3.5 \mathrm{kHz}$ shallow subbottom profiler aboard R/V Tamhae II of the Korea Institute of Geoscience and Mineral Resources in 2002 (Fig. 2A). In 2004, extensive single channel air-gun and Chirp sonar surveys were performed in tidal ridges which projects southwestward from the Kanghwa and Jangbong islands (Fig. 2A). Additionally, sparker seismic and Chirp sonar surveys were performed in proximal tidal ridge from 2007 to 2009 .
This study uses three types of core sediments; deepdrilled cores, piston cores, and discontinuous hammerpressure-cores (Fig. 2A). In 1998 and 2004, deepdrilled sediment cores (YSDP-107 and NYSDP-101) were obtained at the distal ridge top, using aboard drill-ship Khan-407. In 2004, a total of 40 piston cores were retrieved on the tidal ridges and adjacent offshore area. Recently, 4 hammer-pressure-cores were obtained in the tidal channel and tidal flat on proximal tidal ridge. The cores were split lengthwise for visual and X-radiographic descriptions. Grain size was estimated by Microtrac-3000 (Laser Diffraction) in KIGAM. Sedimentary structures were described on Xradiograph. AMS ${ }^{14} \mathrm{C}$ and OSL datings of available materials were conducted at the Institute of Geological and Nuclear Sciences in New Zealand and at the Korea Basic Science Intitute, respectively. 


\section{Previous Works}

According to the previous works, the sedimentary strata in Kyeonggi Bay have been described as three seismic units ( ${ }_{\mathrm{pw}}$ Unit is previous work Unit) in the tidal ridges and offshore area (KIGAM, 2004; Shinn et al., 2007) and two lithostratigraphic units ( ${ }_{\mathrm{pw}}$ Unit I and ${ }_{\mathrm{pw}}$ Unit II) in tidal flats (Table 1; Lim and Park, 2003; Lim et al., 2003; Choi, 2005).

KIGAM (2004) reported that the sedimentary strata in tidal ridges were divided into three seismic units:

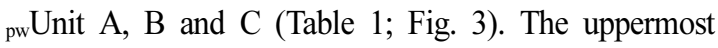
${ }_{\mathrm{pw}}$ Unit A shows continuous inclined or parallel stratification with a partly transparent facies, characterized by wedge-shaped geometry (Fig. 3). The core sediment data indicate that this unit comprises thick (ca. $40 \mathrm{~m}$ thick) muddy sediments in distal tidal ridges, whereas in offshore area it is represented by relatively thin (less than $5 \mathrm{~m}$ thick) shelf sands. This unit was most likely formed during the Holocene
Table 1. Summary of stratigraphic schemes of previous works

\begin{tabular}{|c|c|c|}
\hline & Seismic units & $\begin{array}{l}\text { Lithostratigraphic } \\
\text { units }\end{array}$ \\
\hline \multirow{3}{*}{$\begin{array}{c}\text { Stratigraphy } \\
\text { of previous study } \\
\text { (Lim and Park, 2003; Lim } \\
\text { et al., 2003; Choi, 2005) }\end{array}$} & ${ }_{\mathrm{pw}}$ Unit A & ${ }_{\mathrm{pw}}$ Unit I \\
\hline & ${ }_{\mathrm{pw}}$ Unit B & ${ }_{\mathrm{pw}}$ Unit II \\
\hline & ${ }_{\mathrm{pw}}$ Unit C & Basement \\
\hline
\end{tabular}

highstand (KIGAM, 2004).

${ }_{\mathrm{pw}}$ Unit $\mathrm{B}$ is the middle seismic unit in tidal ridges with about $35 \mathrm{~m}$ in thickness, overlain by ${ }_{\mathrm{pw}}$ Unit $\mathrm{A}$ (Fig. 3). This unit is characterized by discontinuous reflection and channel-fill geometry (Fig. 3). In channelfill deposits, internal reflectors converge with a downlap configuration. The unit consists of sand-dominated or sand-mud heterolithic facies, which has been interpreted as fluvial deposits formed during preHolocene lowstand period (Jin, 2001; KIGAM, 2004).

The lowermost ${ }_{\mathrm{pw}} \mathrm{Unit} \mathrm{C}$ rests on acoustic basement, overlain by ${ }_{p w}$ Unit $\mathrm{B}$ (Fig. 3). The unit ranges in thickness from 30 to 50 meters in tidal ridges, and
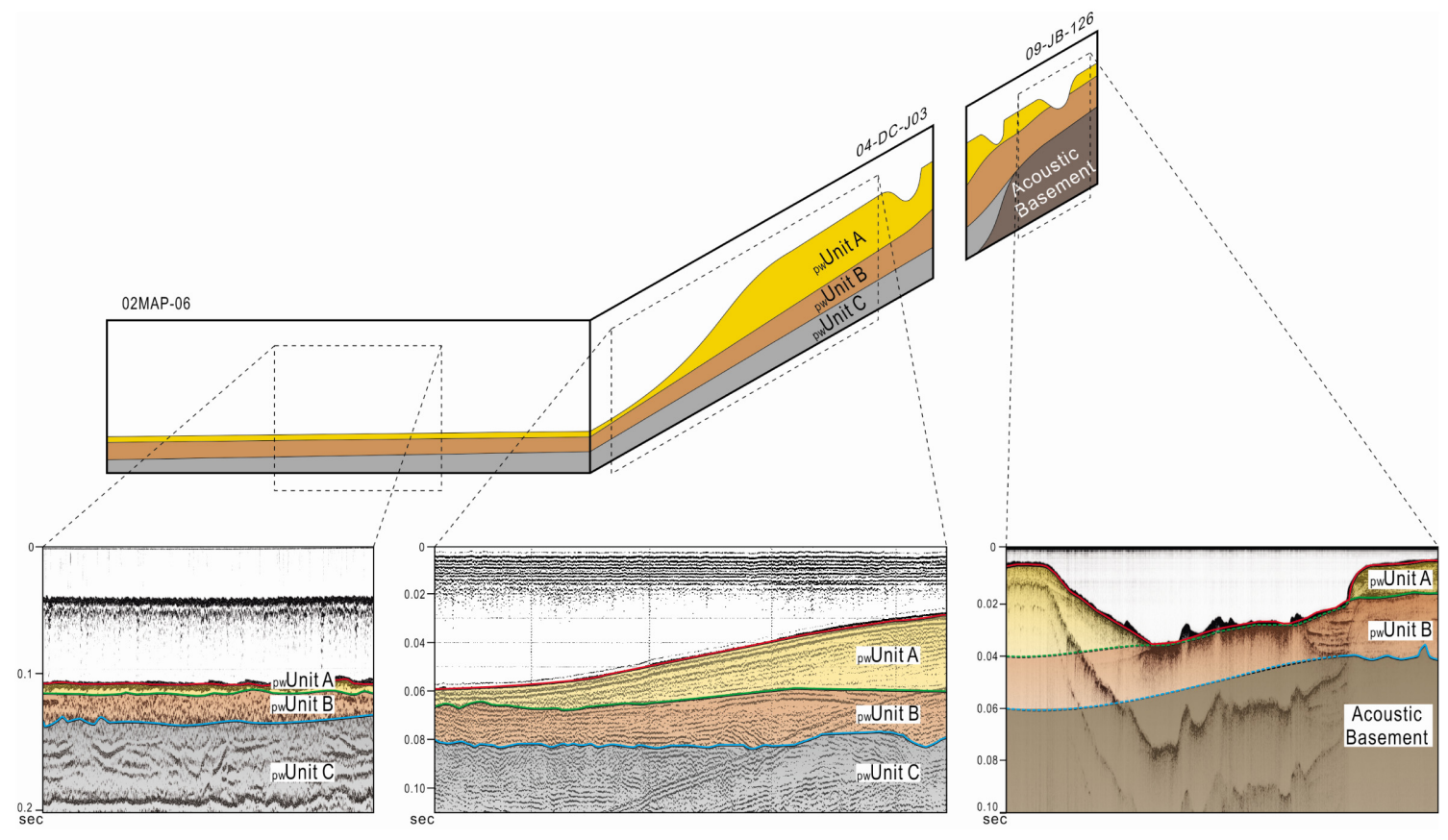

Fig. 3. Summary of the previous stratigraphic interpretations in Kyeonggi Bay. On the three seismic track lines (02MAP-06, 04DC-J03, and 09-JB-126), the previous stratigraphic units ( ${ }_{p w} U n i t ~ A,{ }_{p w} U n i t ~ B$, and $\left.{ }_{p w} U n i t ~ C\right)$ are correlated in the tidal flat to offshore areas (see Fig. 2A for the track lines). Vertical depth of the seismic profiles is expressed with two-way travel time in seconds. 


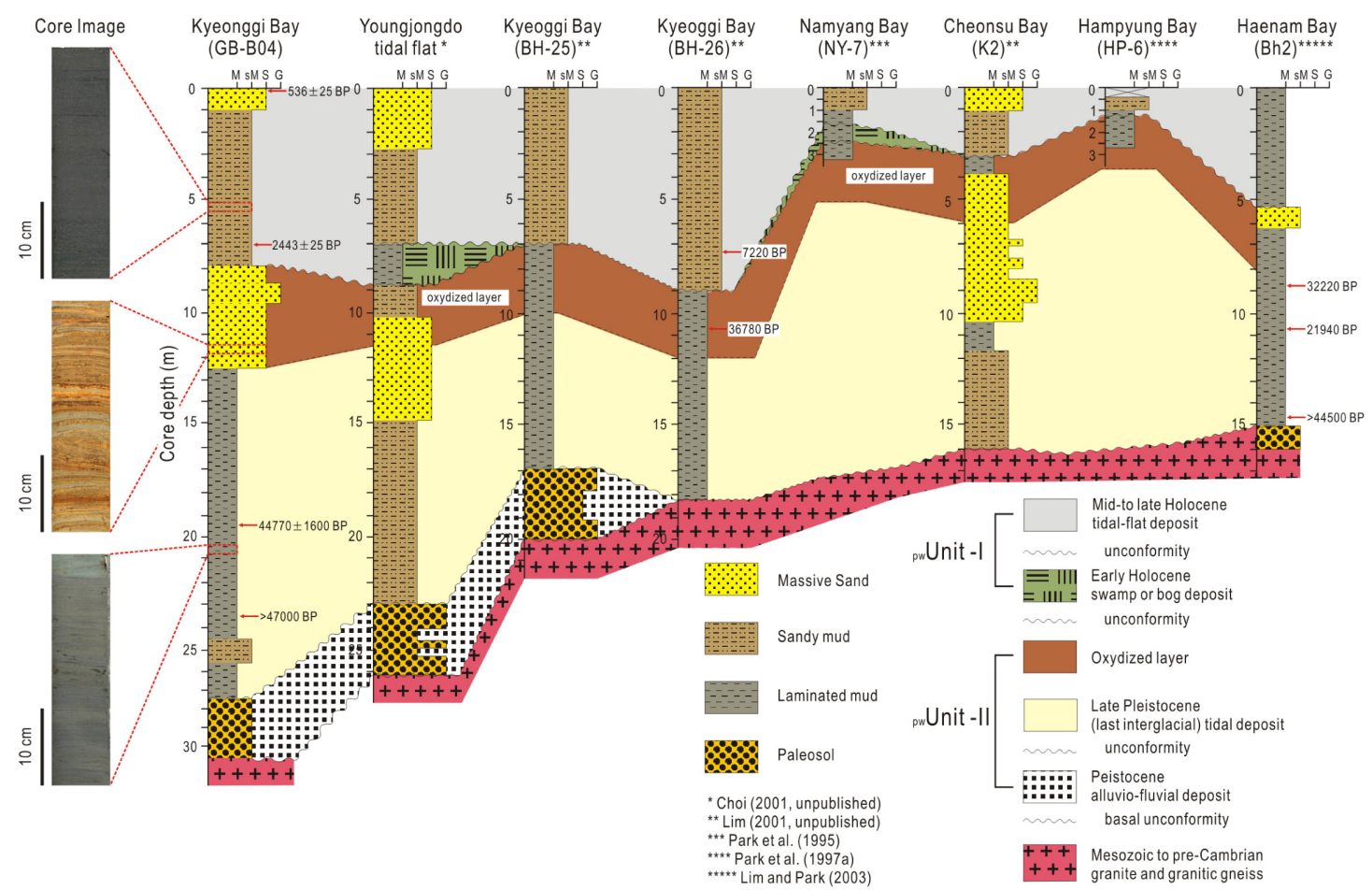

Fig. 4. Stratigraphic correlation of tidal flat successions distributed in the western coast of Korean Peninsula, showing lithologic and radiocarbon age information (modified from Lim and Park, 2003).

decreases in thickness in the distal part of the tidal ridges. Due to attenuation of seismic energy and multiple reflectors, it is difficult to describe seismic facies and boundary characters, but ${ }_{p w}$ Unit $\mathrm{C}$ is represented by discontinuous and chaotic seismic facies (Fig. 3). The core sediments are composed of sand-dominated facies frequently alternated with muddy stratifications of tidal origin. This unit was interpreted as pre-Holocene transgression or highstand deposits (KIGAM, 2004). The pre-Holocene transgression and highstand probably indicates a period from MIS6 lowstand (ca. $130 \mathrm{ka}$ ) to MIS-5 highstand (ca. 120$80 \mathrm{ka})$.

The stratigraphic scheme in tidal flats of Kyeonggi bay is slightly different from the scheme in offshore area and tidal ridges (Fig. 3). Late Quaternary strata in tidal flats of western coasts of Korea have been divided commonly into two units: ${ }_{\mathrm{pw}}$ Unit I and ${ }_{\mathrm{pw}}$ Unit II (Table 1; Jin and Chough, 1998; Park et al., 1998; Chun et al., 2000; Choi et al., 2001; Lim and Park, 2003; Lim et al., 2003; Choi, 2005). The two units are separated by an oxidized and desiccated sedimentary layer (Fig. 4). pwUnit I consists mostly of soft, grayish mud and sandy silt, ranging from 3 to 8 $\varnothing$ in mean grain size. It can be interpreted as a typical tidal flat sequence of mid-to-late Holocene (Fig. 4; Frey et al., 1989; Chang et al., 1996; Kim et al., 1999; Lim, 2001; Lim and Park, 2003; Lim et al., 2003).

The underlying ${ }_{\mathrm{pw}}$ Unit II rests on acoustic basement rocks (Figs. 3 and 4), and is known to be laterally persistent throughout the western coasts of the Korean Peninsula, even though it varies in thickness and in depth (Fig. 4; Lim et al., 2003). The unit is divided into the lower, middle, and upper layers. The upper layer might have been exposed and weathered to yield a yellowish oxidized layer (Fig. 4). This layer was interpreted as subaerial exposure surfaces of the preHolocene sediments (Lim and Park, 2003; Lim et al., 2003; Choi, 2005). The previous studies have gathered radiocarbon ages of plant stems from this layer, ranging from $36,780 \pm 450(-17.0 \mathrm{~m}$ MHWL $)$ to 
Table 2. Summary of AMS ${ }^{14} \mathrm{C}$ age dates in Kyeonggi and Haenam bays

\begin{tabular}{cccc}
\hline \hline Location & Core No. & $\begin{array}{c}\text { Depth in core } \\
(\mathrm{m})\end{array}$ & $\begin{array}{c}\text { AMS }{ }^{14} \mathrm{C} \text { age } \\
(\mathrm{yr} \mathrm{BP})\end{array}$ \\
\hline \multirow{4}{*}{ Kyeonggi Bay } & 0.5 & $536 \pm 25$ \\
& & 7.2 & $2,443 \pm 25$ \\
& & 19.3 & $44,700 \pm 1600$ \\
& & 23.6 & $>47,000$ \\
\hline & BH-B04 & 7.0 & 7,220 \\
Haenam Bay 2001$)$ & 11.0 & $36,780 \pm 450$ \\
\hline & BH1 & 1.5 & $1,362 \pm 48$ \\
& (Lim and Park, & 10.5 & $7,250 \pm 100$ \\
& 2003) & 17.0 & $8,524 \pm 69$ \\
\hline & BH2 & 10.2 & $32,200 \pm 770$ \\
& (Lim and Park, & 12.0 & $21,940 \pm 800$ \\
2003) & 15.8 & $>44,500$ \\
\hline
\end{tabular}

44,700 $\pm 1,600$ yr BP ( $-25.3 \mathrm{~m}$ MHWL) (Table 2; Fig. 4). The results indicate that subaerial exposure of the late Pleistocene sediments has lasted at least the late Wisconsin maximum lowstand (Lim et al., 2003). The middle layer of ${ }_{\mathrm{pw}}$ Unit II consists of olive-gray, cohesive, poorly-sorted mud and sand sediments, ranging from 4 to $8 \phi$ in mean grain size (Fig. 4). The layer is very similar to the late Holocene tidal flat sediments of ${ }_{p w}$ Unit I. Lim et al. (2003) and Lim and Park (2003) interpreted that this layer can be matched with the late Pleistocene interglacial tidal sediments with an interpolated age of $125 \mathrm{ka}$ (probably MIS-5e highstand). The lowermost layer, resting on acoustic basements, consists of gravelly sands or paleosols (Fig. 4). The layer was interpreted as lags or fluvial deposits, probably formed during an earlier sea-level lowstand (Lim and Park, 2003).

Table 2 summarizes results of radiocarbon dating undertaken on plant peat and other organic matters and shows chronostratigraphic scheme for ${ }_{\mathrm{pw}}$ Units I and II. Resultant dates for ${ }_{\mathrm{pw}}$ Unit II are 25,220 $\pm 200 \mathrm{yr}$ BP (-8.1 m MHWL), 32,200 \pm 770 yr BP $(-10.2 \mathrm{~m}$ MHWL), 21,940 $\pm 800 \mathrm{yr}$ BP $(-12.0 \mathrm{~m} \mathrm{MHWL})$, and $44,500 \pm 1,600$ yr BP $(-25.3 \mathrm{~m}$ MHWL). In Kyeonggi Bay, the dates are $36,780 \pm 450$ yr BP $(-17.0 \mathrm{~m}$ MHWL) and 44,770 $\pm 1,600 \mathrm{yr}$ BP ( $-25.3 \mathrm{~m}$ MHWL) (Fig. 4). These data indicate deposition of ${ }_{\mathrm{pw}}$ Unit II during the Wisconsinan glacial period (MIS-3; ca. 25-
$50 \mathrm{ka}$ BP). According to Lim and Park (2003), however, these dates cannot be taken at face value. From 25 to $50 \mathrm{ka} \mathrm{BP}$, eustatic sea level is known to have been about $40-80 \mathrm{~m}$ below the present mean sea level, as constrained by the global glacio-eustatic sealevel record (Chappell and Shackleton, 1986; Cann et al., 1988; Chappell et al., 1996). The elevation of tidal flat deposits of ${ }_{\mathrm{pw}}$ Unit II is too high to have developed during the last interstadial interval, highlighting a mismatch between the inferred sea-level history, based on radiocarbon dates, and the global eustatic sea-level curve. Lim and Park (2003) reasonably discussed that acceptance of these dates would require an uplift in western coasts of the Korean Peninsula by at least 40 $\mathrm{m}$ since the last interstadial. However, evidences of a significant neotectonic uplift or a higher sea-level stand along the western coasts have not been recognized elsewhere. The too young dates have been interpreted as the result of carbon contamination of pre-Holocene sediment during subaerial exposure at the time of the last glacial maximum (LGM) (Lim and Park, 2003). According to Yim et al. (1990) and Nichol and Murray-Wallace (1992), radiocarbon dates (20-40 ka BP) for pre-Holocene marine sediments from the coast of Hong Kong and Narrawalle Estuary of New South Wales were considerably younger than dates provided by uranium-series and amino-acid racemization datings (120-130 ka BP). Consequently, Lim et al. (2003) proposed that middle layer of ${ }_{\mathrm{pw}} \mathrm{Unit}$ II was probably deposited during MIS-5 (ca. 70-130 ka BP), because the radiocarbon ages of organic matter from ${ }_{\mathrm{pw}}$ Unit II should be considered as minimum values.

\section{Results}

\section{Core analysis}

The stratigraphy and depositional environments of the tidal flat in Kyeonggi Bay was reconstructed based on facies analysis and age dating (Choi et al., 2012). The tidal flat succession can be divided into four major lithologic units (Unit-1, Unit-2, Unit-3 and Unit-4) (Fig. 5). The major units are separated by sharp boundaries and uncomformity. 


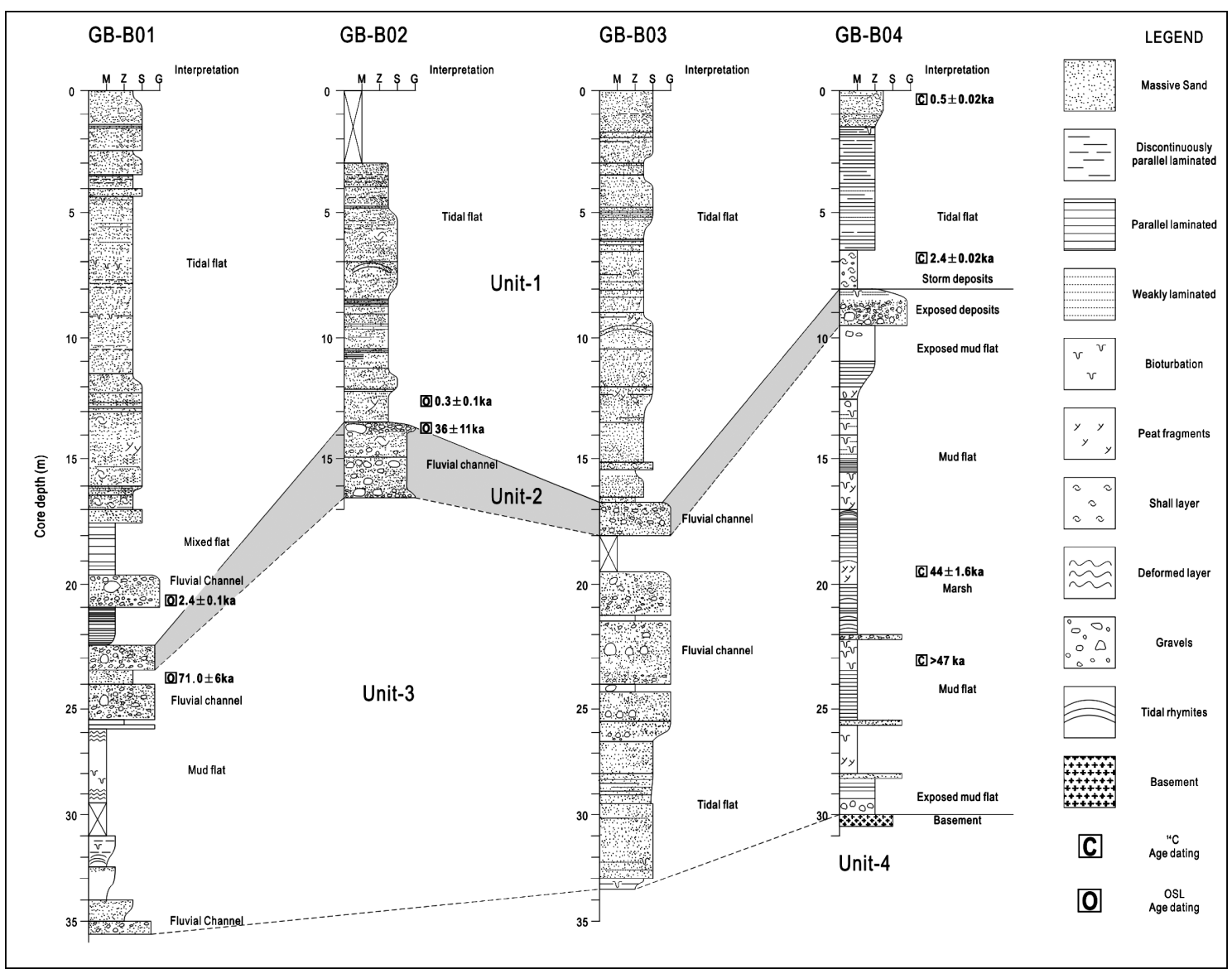

Fig. 5. Core sediment description and stratigraphic interpretation of tidal flat successions in Kyeonggi Bay, showing four major lithologic units (Unit-1, Unit-2, Unit-3, and Unit-4).

The uppermost Unit-1 is 8 to $20 \mathrm{~cm}$ thick in tidal flat deposits. It consists of dark greenish gray to greenish gray sediments, which are composed mostly of sand and silt, varying from 2 to $5 \phi$ in mean grain size. The unit includes a variety of tide-influenced sedimentary structures such as tidal rhythmite and bidirectional ripple-cross laminations. GB-B04 core sediments are characterized by coarsening-upward succession, which has been considered as transgression sequence in the tidal flats of the mid-eastern Yellow Sea (Kim et al., 1999; Park et al., 1999). Common occurrences of shell layers (interval 6-8 $\mathrm{m}$ in GB-B04) are indicative of high-energy conditions such as storms or typhoons (Fig. 5). A number of radiocarbon age dates indicate a Holocene sedimentation of the unit (e.g., Kim et al., 1999; Park et al., 1999).
Unit-2 (1.5 to $4 \mathrm{~m}$ thick) consists of poorly sorted, greenish gray or light yellowish brown, gravelly sand to sandy gravel (Fig. 5). Moderately rounded pebbles up to $4 \mathrm{~cm}$ in diameter are scattered in the gravelly sand unit. It probably formed in fluvial sedimentary environments. This unit is very similar to depositional fabric and facies of channel-fill facies within the underlying Unit-3. According to OSL age dating $(36,000 \pm 1,100$ yr BP) in GB-B02 core, this unit is interpreted as fluvial deposits in the MIS-3 period (Table 3).

Unit-3 is composed of greenish gray, silty sand, and sandy silt sediments (4-7 $\phi$ in grain size). Most of Unit-3 consists of discontinuous laminated and moderately bioturbated silt deposits (Fig. 5). Tidal rhythmite and ichnofabrics are indicative of tidal 
Table 3. Equivalent doses (De), dose rate and OSL ages of the GB-B01 and B02 in Kyeonggi Bay

\begin{tabular}{cccccc}
\hline \hline Sample Code & $\begin{array}{c}\text { Dose Rate } \\
(\mathrm{Gy} / \mathrm{ka})\end{array}$ & $\begin{array}{c}\text { Water content } \\
(\%)\end{array}$ & $\begin{array}{c}\text { Equivalent dose } \\
(\mathrm{Gy})\end{array}$ & $\begin{array}{c}\text { Aliquots used } \\
(\mathrm{n})\end{array}$ & $\begin{array}{c}\text { OSL age } \\
(\mathrm{ka}, \mathrm{SD})\end{array}$ \\
\hline GB-B01 $(20.5 \sim 21.0 \mathrm{~m})$ & $3.17 \pm 0.08$ & 27.0 & $7.5 \pm 0.3$ & 24 & $2.4 \pm 0.1$ \\
GB-B01 $(23.5 \sim 24.0 \mathrm{~m})$ & $3.22 \pm 0.08$ & 24.5 & $230 \pm 19$ & 24 & $71 \pm 6$ \\
GB-B02 $(12.0 \sim 12.5 \mathrm{~m})$ & $3.45 \pm 0.09$ & 24.6 & $1.0 \pm 0.3$ & 24 & $0.3 \pm 0.1$ \\
GB-B02 $(13.5 \sim 14.0 \mathrm{~m})$ & $3.36 \pm 0.09$ & 12.2 & $120 \pm 36$ & 22 & $36 \pm 11$ \\
\hline
\end{tabular}

sedimentation. In particular, sedimentary features such as tidal rhythmites and herringbone structures have been reported from equivalent late Pleistocene units in other Korean tidal flats (Park and Choi, 1998; Lim, 2001). The age dates from OSL method is $71,000 \pm$ $600 \mathrm{yr}$ BP, suggesting that this unit formed in the MIS-5 period (Table 3; Fig. 5).

The lowermost Unit-4 comprises deeply weathered sedimentary rocks. Detailed fabric and structures are hardly described due to weathering processes. According to previous works, this unit was deposited in a depth of $30 \mathrm{~m}$ at the tidal flat of Yellow Sea (Choi, 2001; Lim and Park, 2003; Lim et al., 2003).

\section{Revised seismic stratigraphy}

The air-gun and sparker seismic profiles taken in offshore area, tidal ridges, and shallow subtidal area of Kyeonggi Bay, show the presence of several seismic stratigraphic units bounded by regional unconformities or disconformities. This study recognizes four seismic units named SU-1 to SU-4 (Table 4; Fig. 6).

Seismic unit-1 (SU-1) consists of ridge-forming sediments, represented by inclined prograding reflection and wedge-shaped geometry, relatively thin (less than a few meters thick) offshore shelf sands (or muds), and tidal flat sediments (Fig. 6). This unit corresponds to unit $\mathrm{A}$ of the previous stratigraphic scheme (Table 4).

The underlying seismic unit-2 (SU-2) is correlated with the top of unit $\mathrm{B}$ in the previous stratigraphic schemes in the distal tidal ridges and offshore area of Kyeonggi Bay (Table 4), whereas SU-2 pinched out, forming coastal onlap below the present front of tidal ridges (Fig. 6). The unit shows crudely stratified, discontinuous reflection with a part of chaotic reflection, discriminated from the underlying unit-3 by diffuse discontinuous boundary at $70-80 \mathrm{~ms}$ by two way travel time below the present sea level.

The seismic unit-3 (SU-3) is characterized by intensively multi-stacked bank and channel-fill facies (Fig. 6). The bank facies are relatively stratified, occasionally showing stepped collapses, whereas the channelized structures are filled with chaotic and transparent facies (Fig. 6). In some parts, active migration of channel-fill facies is observed. This unit corresponds to unit $\mathrm{C}$ of the previous stratigraphic scheme in the front of distal tidal ridges and offshore area, whereas includes both of units $\mathrm{B}$ and $\mathrm{C}$ in the landward distal and proximal tidal ridges and tidal flats (Table 4).

The lowermost seismic unit-4 (SU-4) is ambiguously distinct from the overlying seismic unit-3 by highamplitude reflector at about $110-120 \mathrm{~ms}$ by two way travel time below the present sea level (Fig. 6). Because internal reflectors and reflection facies are masked and duplicated by multiple reflections, it is difficult to describe internal structure and facies of the unit and to interpret depositional processes and environments.

\section{Depositional sequences}

The late Quaternary seismic stratigraphic units (SU1 to SU-4) can be considered as depositional sequences (DS-1, DS-2, DS-3, and DS-4). According to facies analysis and age dating on deep-drilled YSDP-107 cores (Fig. 7), depositional sequence-1 (DS-1) was interpreted as tidal-flat and estuarine channel-fill deposits formed during the Holocene highstand. Age dates from the inner ridges or tidal flats of this sequence also indicate the Holocene deposition (Table 2). DS-1 consists of muddy sediments in tidal flats, whereas of subtidal sand-prone facies in the proximal 


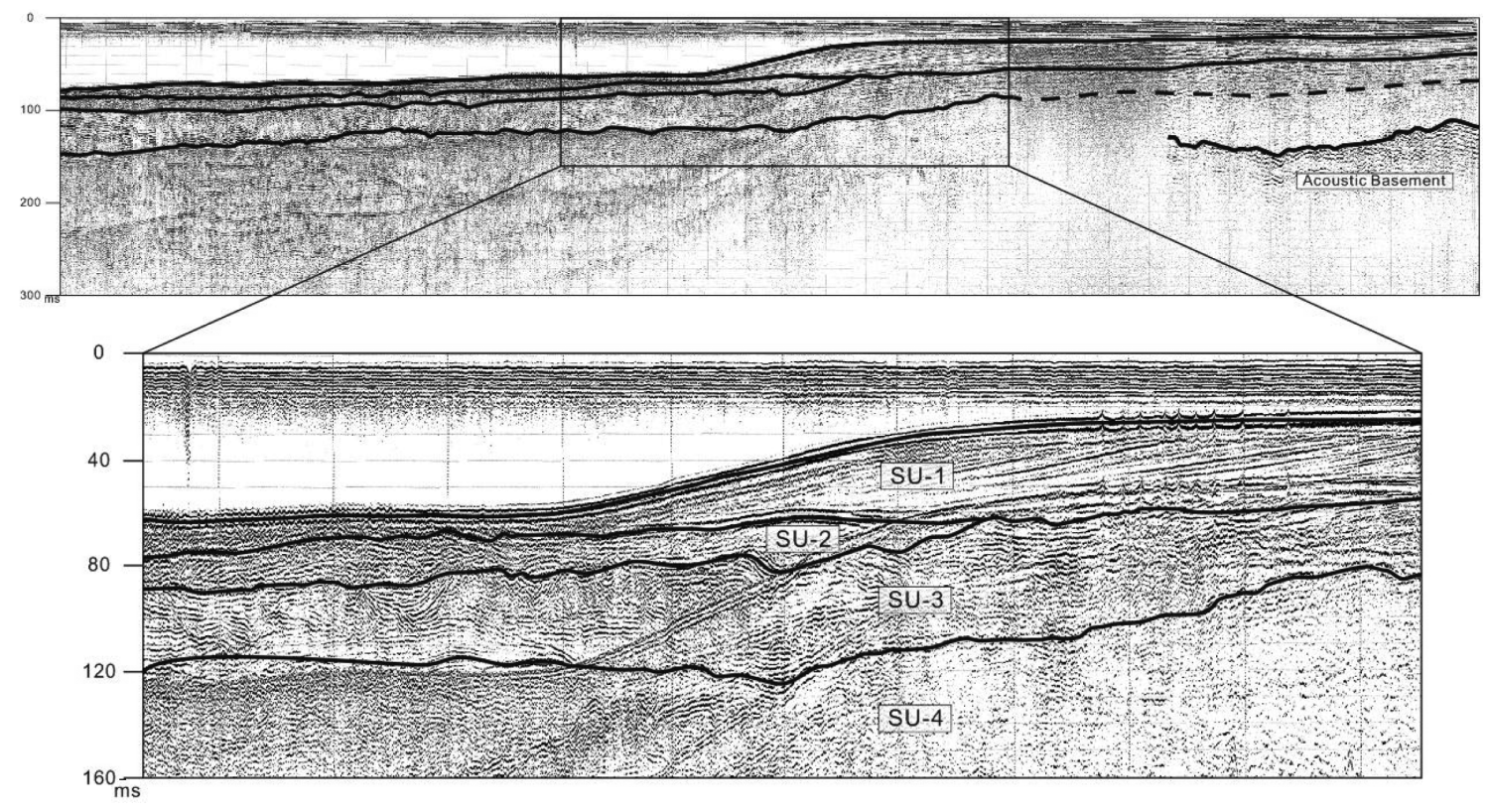

Fig. 6. Late Quaternary seismic stratigraphy of Kyeonggi Bay, revised in this study (Choi et al., 2012). Vertical depth of the seismic profiles is expressed with two-way travel time in milliseconds.

Table 4. Comparison of seismic stratigraphic schemes between previous work and this study

\begin{tabular}{|c|c|c|c|}
\hline & \multirow{2}{*}{$\begin{array}{l}\text { Previous scheme } \\
\text { (KIGAM, 2004) }\end{array}$} & \multicolumn{2}{|c|}{ This study } \\
\hline & & Offshore $\leftarrow$ & $\rightarrow$ Proximal ridge \\
\hline \multirow{4}{*}{ Stratigraphy } & pw Unit A & \multicolumn{2}{|c|}{ Seismic Unit-1 } \\
\hline & pwUnit B & Seismic Unit-2 & \\
\hline & pwUnit C & \multicolumn{2}{|c|}{ Seismic Unit-3 } \\
\hline & Acoustic Basement & \multicolumn{2}{|c|}{ Seismic Unit-4 } \\
\hline
\end{tabular}

tidal ridges. In the distal tidal ridges, it comprises mud-prone facies, which gradually changes into shelf sand facies in offshore area.

DS-2 is divided into outer shallow-marine and inner fluvial channel-fill successions (Fig. 7). Piston core sediments (04DC-P08 and -P11) show that outer shallow-marine successions of DS-2 are composed of bioturbated mud facies capped by dark yellow or brownish sands (Fig. 7). Age dates are 20,270 $\pm 110 \mathrm{yr}$ BP (-53.1 $\mathrm{m} \mathrm{MHWL)} \mathrm{and} \mathrm{18,472 \pm 90} \mathrm{yr} \mathrm{BP}(-51.7 \mathrm{~m}$ MHWL). The results indicate shallow subtidal deposition during the MIS-3 period and subsequent exposure during the last glacial maximum (Table 2). On the other hand, inner fluvial successions of DS-2 consist of fluvial sand-prone facies with a sharp erosional upper contact (Fig. 7). The lowermost part (ca. $75-80 \mathrm{~m}$ below sea level) in YSDP-107 was interpreted as fluvial channel sand deposits (Jin, 2001; KIGAM, 2004). The fluvial sequence was dated by radiocarbon dating method at 27,260 $\pm 300 \mathrm{yr}$ BP (-75.1 $\mathrm{m}$ MHWL) (Jin, 2001). The occurrence of deeply incised fluvial channel deposits suggests that intensive incision and erosion occurred during the last glacial maximum (Fig. 8).

Depositional sequence-3 (DS-3) is characterized by intense fluvial or tidal incision, showing active migration of fluvial or tidal channels (Fig. 7). The upper part of the sequence is divided into outer fluvial/estuarine channel and inner tidal-flat facies (Figs. 4 and 7). Inner tidal-flat facies unit was probably formed during the MIS-5e highstand (Fig. 8). The highstand deposits can be correlated with lower 


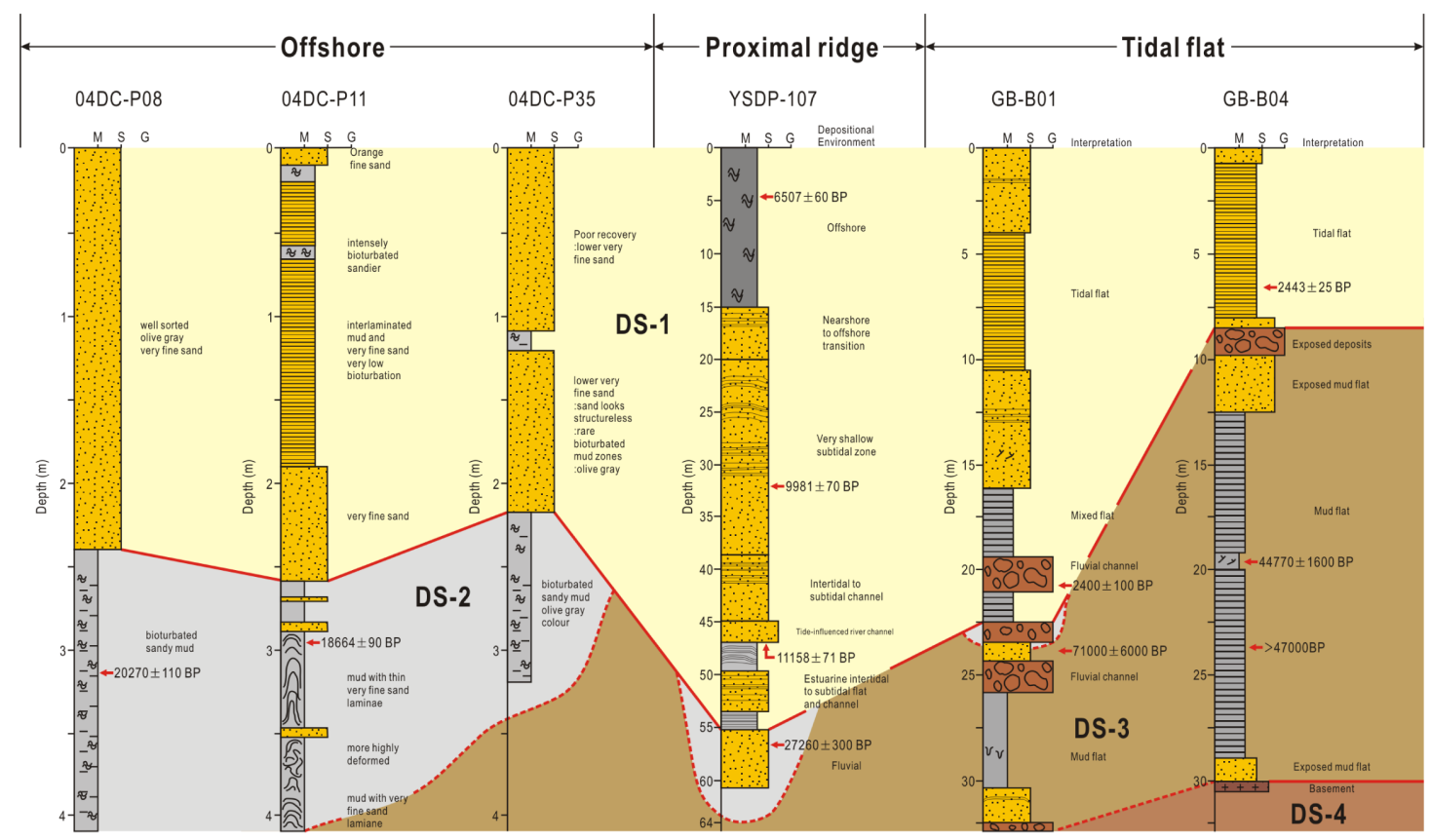

Fig. 7. Stratigraphic correlation of several sediment cores in offshore area (04DC-08, -11, and -35), sand ridge (YSDP-107), and tidal flats (GB-B01 and -B04). See Fig. 2A for location.

part of DS-3 in the offshore and distal ridge areas (Fig. 8). As shown in seismic interpretation, the upper DS-3 was strongly affected by fluvial or estuarine channel processes (Figs. 6 and 8). The upper sequence probably formed by normal regression reiterated by higher order fluctuations during the period from MIS5e highstand to -4 lowstand (Fig. 8).

The lowermost DS-4 probably rests on the Mesozoic or Precambrian basement rocks. The unit is considered as the shallow-marine and shelf deposits formed before the MIS-6 lowstand.

\section{Discussion}

\section{Late Quaternary sequence model}

The very shallow epicontinental Yellow Sea has sensitively responded to high-amplitude sea-level fluctuations during the late Pleistocene. The repeated broad inundation and exposure produced typical transgression-regression successions with extensive exposure surfaces in shelf areas. This study suggests a new sequence model in the Yellow Sea (Fig. 9). The model constitutes six depositional stages (Stage A to F).

Stage-A is correlated with the MIS-6 lowstand period (ca. 150-135 ka BP). The eustatic sea-level fall in stage-A subaerially exposed most of shelf area, and caused fluvial incision and weathering processes (Fig. 9A). The formation of DS-4 predated the MIS-6 lowstand period (Table 5).

The subsequent rapid and high amplitude (more than $100 \mathrm{~m}$ in height) rise of sea level in stage-B produced transgressive deposits in the lowermost part of the MIS-5 sequence (DS-3) until the MIS-5e highstand (ca. 135-115 ka BP) (Table 5; Fig. 9B).

The successive fall of sea level with higher order fluctuations in stage-C during the MIS-5d to $-5 \mathrm{a}$ and MIS-4 lowstand period (ca. 115-60 ka BP) formed highstand and/or forced regressive deposits in the upper part of the MIS-5 sequence (DS-3) (Table 5; Fig. 9C). The upper part is predominated by highstand tidal flat deposits in the proximal ridges and forced regressive deposits in the distal ridges (Fig. 8). The drastic sea-level drop from the MIS-5a to MIS-4 

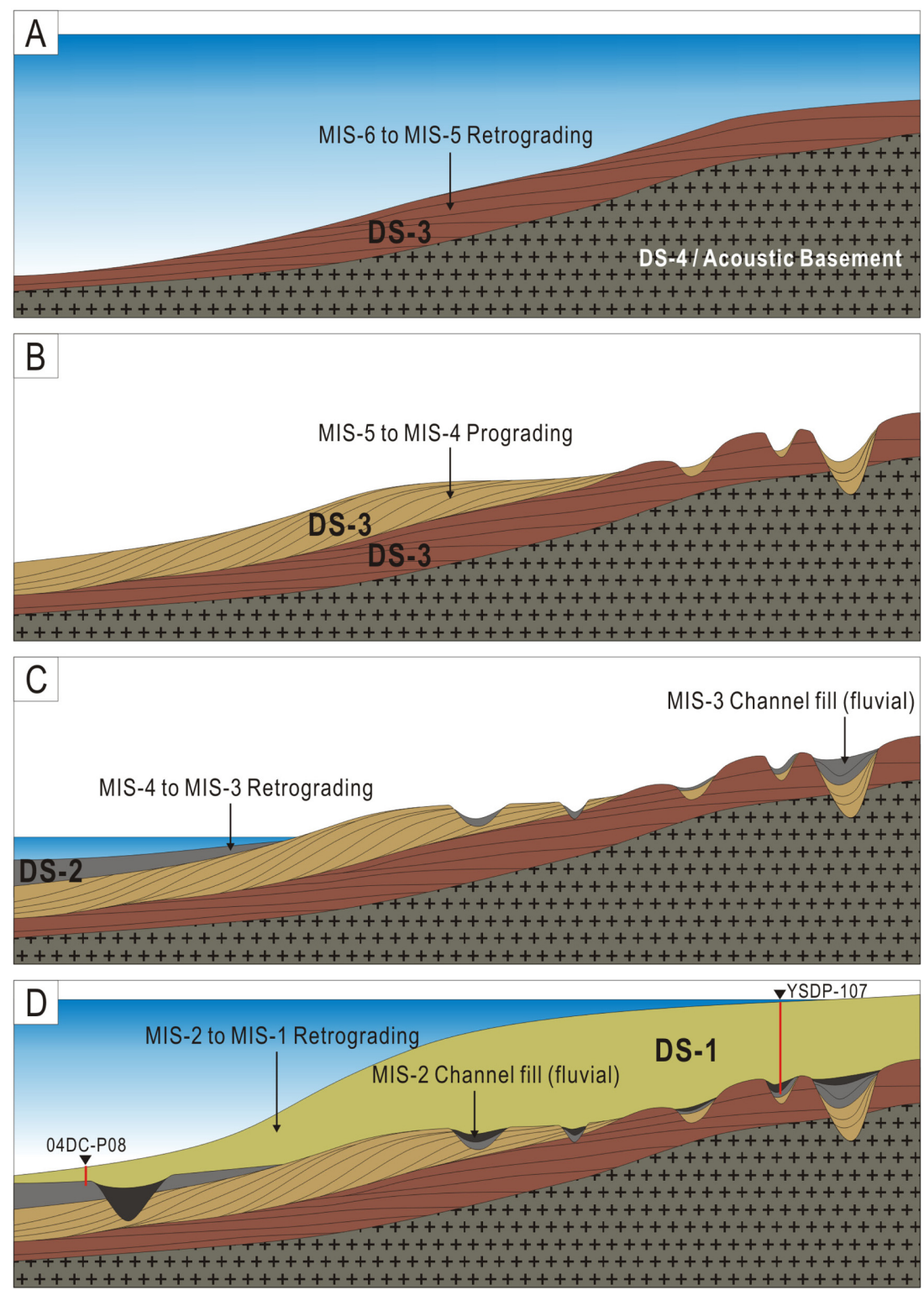

Fig. 8. Conceptual depositional history of late Quaternary sequences in Kyeonggi Bay.

lowstand period exposed broad area of shallow shelf above at a depth less than $60-80 \mathrm{~m}$ below the present sea level. The exposure and accompanying fluvial processes intensively eroded and incised the MIS-5 sequence, forming mainly channel-fill complexes (Fig. 9C). The MIS-4 lowstand marine deposits have not been recognized in previous records, but are only postulated in this model.

Stage-D during the MIS-4 lowstand and MIS-3c highstand period (ca. 60-50 ka BP) explains formation of the transgressive MIS-3 sequence (DS-2) in subtidal area, and continued fluvial incision and channel-fill deposition in exposed area (Table 5; Fig. 9D). The subsequent sea-level fall took place until the last glacial maximum (Stage-E, ca. 50-15 ka BP), forming shallow- marine regressive deposits of MIS-3 sequence (DS-2) and MIS-2 lowstand sequence somewhere more deep (Table 5; Fig. 9E). The exposed regressive 

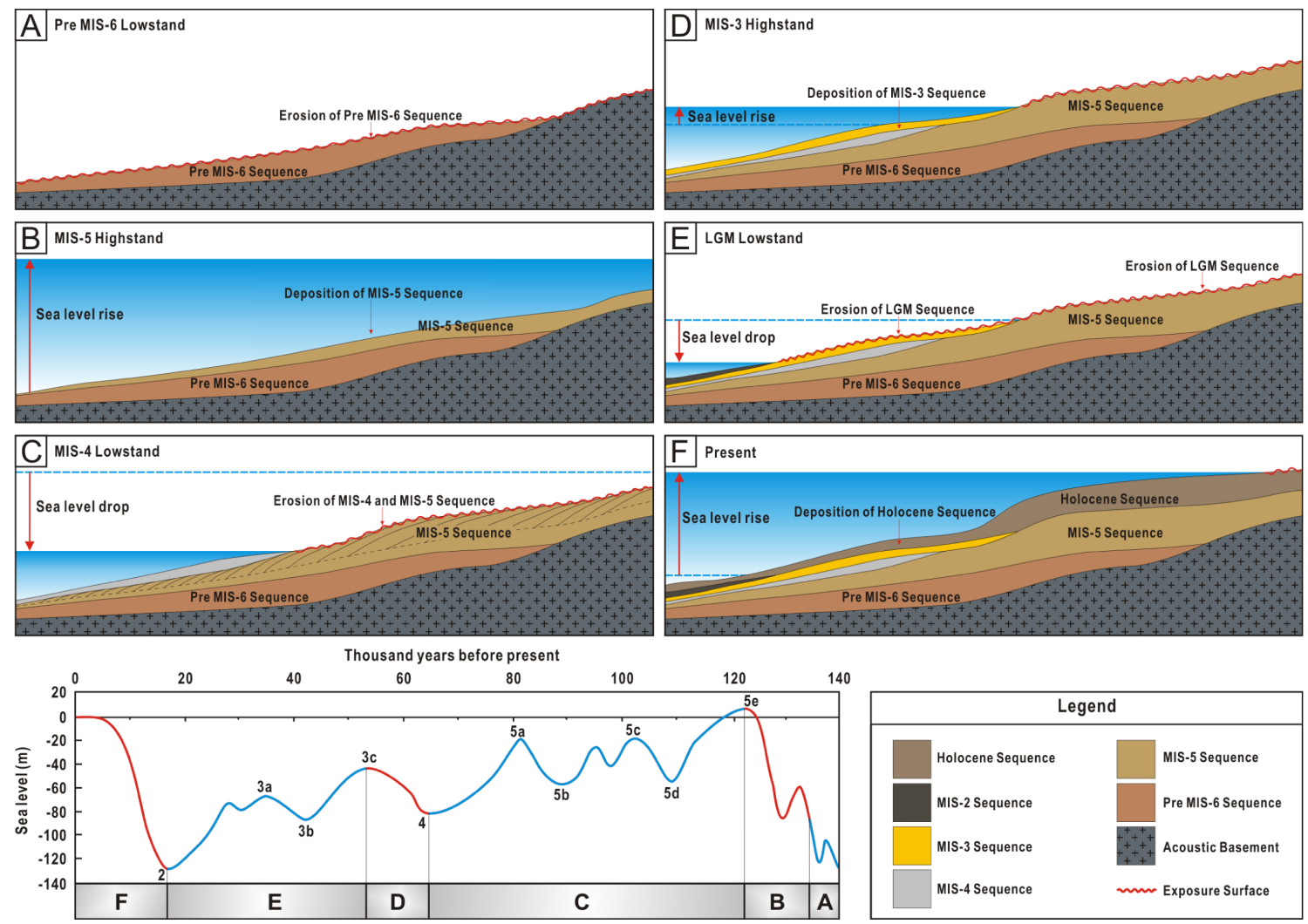

Fig. 9. New sequence model in the late Quaternary in Kyeonggi Bay, mid-eastern Yellow Sea. This model consists of six depositional stages (Stage A to F).

Table 5. Summary of late Quaternary stratigraphy in Kyeonggi Bay and sea-level curve

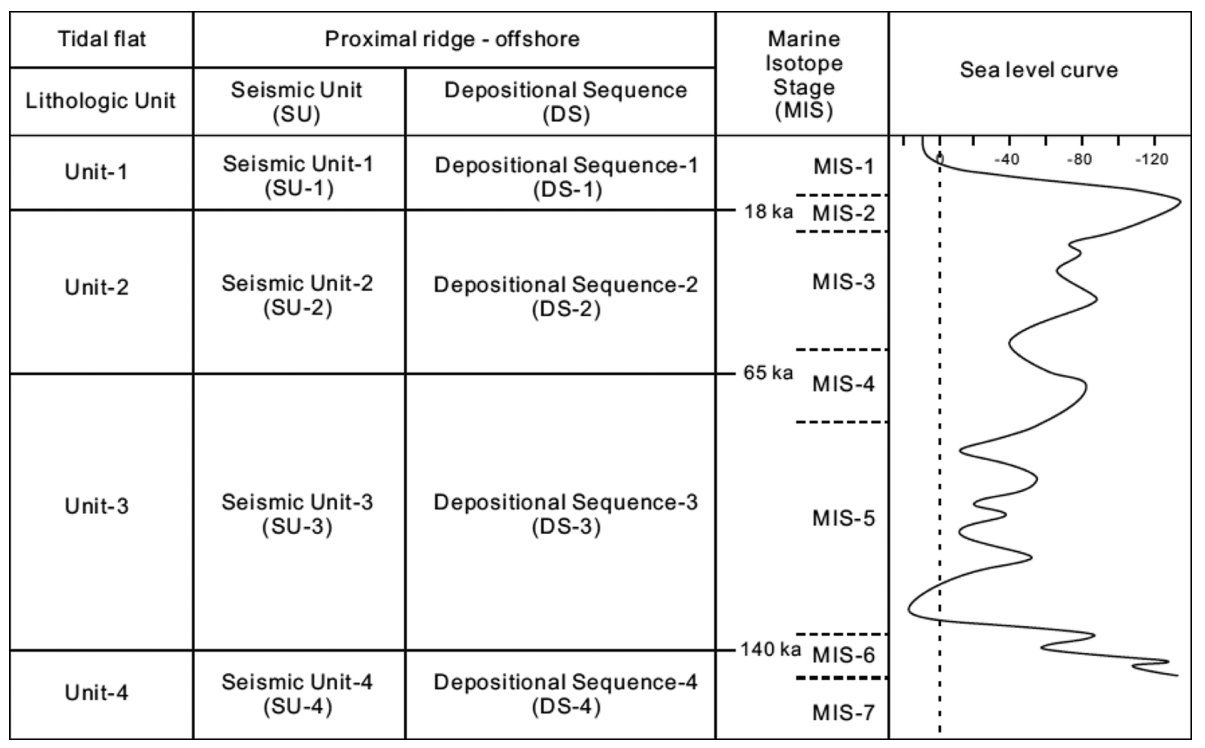


surface was channelized by fluvial incision and subaerial weathering processes.

After the last glacial maximum, the overall Yellow Sea shelf was inundated by the Holocene transgression and highstand (ca. $15 \mathrm{ka} \mathrm{BP}$ to present), forming the Holocene transgressive shelf sands and the tidal ridges (DS-1) (Table 5; Fig. 9).

\section{Paleo-coastline elevation}

Two major shelf-crossing transgressions occurred during the late Quaternary, between MIS-6 and -5 e, and MIS-2 and -1 (Skene et al., 1998). In between, minor transgression (MIS-4 lowstand to MIS-3c highstand) occurred in the early Wisconsinan glacial period (Chappell et al., 1996).

According to Chappell and Shackleton (1986) and Chappell et al. (1996), eustatic sea-level curves indicate that sea level during the MIS-5e (i.e., the Sangamonian/Eemian highstand) was $2-10 \mathrm{~m}$ above the present sea level. Although the raised marine deposits have not been recognized along the western coasts of the Korean Peninsula, tidal flat, and shallow subtidal sequences formed during the MIS-5e highstand are found just below the present sea level less than $10 \mathrm{~m}$ in depth (Table 2). It means that the sea level at the MIS-5e highstand reached almost to the present sea level or jumped over.

After the MIS-5e highstand until the Holocene highstand, sea level fluctuated several times but was never higher than $-30 \mathrm{~m}$ in the East China Sea (Berné et al., 2002). The records of the MIS-5c and $-5 \mathrm{a}$ highstands might be concealed within the regressive MIS-5 sequence. The records of the next MIS-3c highstand are recognized by coastal onlap and/or landward pinch-out configuration of the MIS-3 sequence (Fig. 7). The elevation of the paleo-coastline during the MIS-3c highstand was approximated at about -55 to $-60 \mathrm{~m}$ below the present sea level.

Passing through the last glacial maximum, the Yellow Sea shelf was entirely exposed and shoreline retreated seaward to outer shelf in the East China Sea. The resumed rise of sea level caused inundation of the overall Yellow Sea shelf, forming the broad Holocene sedimentation.

\section{Conclusions}

1. The late Quaternary strata in Kyeonggi Bay consist of four seismic stratigraphic units (SU-1, SU2, SU-3, and SU-4), bounded by regional unconformities or disconformities. The uppermost seismic unit (SU-1) is composed of ridge-forming sediments, represented by inclined prograding reflection and wedge-shaped geometry. The underlying seismic unit (SU-2) pinched out, forming coastal onlap below the present front of tidal ridges. The seismic unit 3 is overlain by SU-2 in offshore area and distal tidal ridges and by SU-3 in the proximal tidal ridges, comprising intensively multistacked bank and channel-fill facies. The lowermost seismic unit 4 rests on acoustic basement, discriminated from SU-3 by continuous high-amplitude reflector at 110-120 ms below the present sea level.

2. Each seismic units in Kyeonggi Bay (SU-1, SU2, SU-3, and SU-4) are considered as depositional sequences. DS-1 was interpreted as tidal flat and estuarine channel-fill deposits formed during the Holocene highstand. DS-2 is divided into outer shallow-marine and inner fluvial facies units, indicative of shallow subtidal deposition during the MIS-3 period and subsequent exposure during the last glacial maximum. DS-3 consists of the lower transgressive facies unit and the upper highstand tidalflat facies in the proximal ridges and forced regression facies in the distal ridges and offshore area. The lowermost DS-4 probably rests on the Mesozoic or Precambrian basement rocks. The unit is considered as the shallow-marine and shelf deposits formed before the MIS-6 lowstand.

3. This study suggests a new sequence model of six depositional stages. Stage-A is a period during the MIS-6 lowstand (ca. 150-135 ka BP) when the eustatic sea-level fall subaerially exposed most of shelf area, and generated fluvial incision and weathering on preMIS-6 sequence. The subsequent rapid and high amplitude (more than $100 \mathrm{~m}$ in height) rise of sea level in stage-B till the MIS-5e highstand (ca. 135-115 
ka BP) produced transgressive deposits in the lowermost part of the MIS-5 sequence. In stage-C during the MIS-5d to -5a and MIS-4 lowstand period (ca. 115-60 ka BP), the highstand and/or forced regressive deposits formed on the trangressive surface. Stage-D during the MIS-4 lowstand and MIS-3c highstand period (ca. 60-50 ka BP) explains formation of the transgressive MIS-3 sequence in a subtidal environment characterized by repetitive fluvial incision and channelfill deposition in exposed area. The subsequent sealevel fall until the last glacial maximum (Stage-E, ca. 50-15 ka BP) made shallow-marine regressive deposits of MIS-3 sequence and MIS-2 lowstand sequence somewhere more deep. After the last glacial maximum, the overall Yellow Sea shelf was inundated by the Holocene transgression and highstand (Stage-F, ca. 15 ka BP to present), forming the Holocene transgressive shelf sands and the tidal ridges.

\section{Acknowledgments}

This work was supported by the Energy Efficiency \& Resources of the Korea Institute of Energy Technology Evaluation and Planning (KETEP-NP2011-036) grant funded by the Korea government Ministry of Knowledge Economy. I am grateful to J.Y. Choi for his scientific discussions and experimental helps. I am also grateful to two anonymous reviewers and the journal editors for useful and constructive comments on the manuscript.

\section{References}

Alexander, C.R., DeMaster, D.J., and Nittrouer, C.A., 1991, Sediment accumulation in a modern epicontinental-shelf setting: the Yellow Sea. Marine Geology, 98, 51-72.

Berné, S., Vagner, P., Guichard, F., Lericolais, G., Liu, Z., Trentesaux, A., Yin, P., and Yi, H.I., 2002, Pleistocene forced regressions and tidal sand ridges in the East China Sea. Marine Geology, 188, 293-315.

Broecker, W.S., Andree, M., Klas, M., Bonani, G., Wolfli, W., and Oeschger, H., 1988, New evidence from the South China Sea for an abrupt termination of the last glacial period. Nature, 333, 156-158.

Cann, J.H., Belperio, A.P., Gostin, V.A., and Murray-
Wallace, C.V., 1988, Sea level history 45,000 to 30,000 years BP, inferred form benthic foraminifera, Gulf St. Vincent, South Australia. Quaternary Research, 29, 153175 .

Chang, J.H., Park, Y.A., and Han, S.J., 1996, Late Quaternary stratigraphy and sea-level change in the tidal flat of Gomso Bay, west coast of Korea. Journal of the Korean Society of Oceanography, 1, 59-72.

Chappell, J. and Shackleton, N.J., 1986, Oxygen isotope and sea levels. Nature, 324, 137-140.

Chappell, J., Omura, A., Esat, T., McCulloch, M., Pandolfi, J., Ota, Y., and Pillans, B., 1996, Reconciliation of late Quaternary sea levels derived from coral terraces at Huon Peninsula with deep sea oxygen isotope records. Earth Planetary Science Letters, 141, 227-236.

Choi, K.S., 2001, Late Quaternary stratigraphy and evolution of tidal deposits in Kyungi Bay, west coast of Korea. Ph.D. Thesis, Unpublished Ph.D. dissertation, Seoul National University, Seoul, Korea, 223 p.

Choi, K.S., Kim, B.O., and Park, Y.A., 2001, Late Pleistocene tidal rhythmites in Kyunggi Bay, west coast of Korea: a comparison with simulated rhythmites based on modern tides and implications for intertidal positioning. Journal of Sedimentary Research, 71, 680691.

Choi, K.S. and Dalrymple, R.W., 2004, Recurring tidedominated sedimentation in Kyonggi Bay (west coast of Korea): similarity of tidal deposits in late Pleistocene and Holocene sequences. Marine Geology, 212, 81-96.

Choi, K.S., 2005, Pedogenesis of late Quaternary marine deposits, northern Kyonggi Bay, Korea: implications for relative sea-level change and regional stratigraphic correlation. Palaeogeography, Palaeoclimatolgy, Palaeoecology, 220, 387-404.

Choi, J.Y., Kwon, Y.K., and Chung, G.S., 2012, Late Quaternary stratigraphy and depoistional environment of tidal sand ridge deposits in Gyeonggi Bay, west coast of Korea. Journal of the Korean Earth Science Society, $33,1-10$.

Chough, S.K., Lee, H.J., and Yoon, S.H., 2000, Marine Geology of Korean Seas. Elsevier, New York, USA, $313 \mathrm{p}$.

Chough, S.K., Lee, H.J., Chun, S.S., and Shinn, Y.J., 2004, Depositional processes of late Quaternary sediments in the Yellow Sea: a review. Geoscience Journal, 8, 211264.

Chun, J.H., Han, S.J., Shin, D.H., Yi, H.I., and Kim, S.R., 2000, Paleoceanographic significance and characteristics of the late Pleistocene oxidized deposits during low sealevel period in the central Yellow Sea. Journal of the Geological Society of Korea, 36, 517-528.

Ergin, M., 1996, Subaerially exposed late-Quaternary basinal shelf of the inner Mersin Bay, eastern 
Mediterranean: paleoenvironmental evidence. GeoMarine Letters, 16, 95-100.

Frey, R.W., Howard, J.D., Han, S.J., and Park, B.K., 1989, Sediments and sedimentary sequences on a modern macrotidal flat, Inchon, Korea. Journal of Sedimentary Petrology, 59, 28-44.

Hardenbol, J., Thierry, J., Farley, M.B., Jacquin, T., de Graciansky, P.C., and Vail, P.R., 1998, Mesozoic and Cenozoic sequence chronostratigraphic framework of European basins. In de Graciansky, P.C., Hardenbol, J., Jacquin, T., Vail, P.R. (eds.), Mesozoic and Cenozoic Sequence Stratigraphy of European Basins, SEPM (Society for Sedimentary Geology) Special Publication, No. 60, SEPM, Tulsa, OK, USA, 3-13.

Jin, J.H. and Chough, S.K., 1998, Partitioning of transgressive deposits in the SE Yellow Sea: a sequence stratigraphic interpretation. Marine Geology, 149, 79-92.

Jin, J.H., 2001, A sedimentological study of long sediment cores in the eastern Yellow Sea. Unpublished Ph.D. dissertation, Seoul National University, Seoul, Korea, $173 \mathrm{p}$.

Jin, J.H. and Chough, S.K., 2002, Erosional shelf ridges in the mid-eastern Yellow Sea. Geo-Marine Letters, 21, 219-225.

Kim, D.S., Park, B.K., and Shin, I.C., 1999, Paleoenvironmental changes of the Yellow Sea during the late Quaternary. Geo-Marine Letters, 18, 189-194.

Kim, J.M. and Kennett, J.P., 1998, Paleoenvironmental changes associated with the Holocene marine transgression, Yellow Sea (Hwanghae). Marine Micropaleontology, 34, 71-89.

Kim, Y.H., Lee, H.J., Chough, S.K., Chun, S.S., and Han, S.J., 1999, Holocene transgressive stratigraphy of a macrotidal flat in the southeastern Yellow Sea: Gomso Bay, Korea. Journal of Sedimentary Research, 69, 328337.

Korea Institute of Geoscience and Mineral Resources (KIGAM), 2004, Study on earth's environmental change using Quaternary sedimentary records: phase I, KIGAM Research Report (KR-04R-05). 221 p.

Lee, H.J. and Yoon, S.Y., 1997, Development of stratigraphy and sediment distribution in the northeastern Yellow Sea during Holocene sea-level rise. Journal of Sedimentary Research, 67, 341-349.

Li, C., Chen, Q., Zhang, J., Yang, S., and Fan, D., 2000, Stratigraphy and paleoenvironmental changes in the Yangtze delta during the late Quaternary. Journal of Asian Earth Science, 18, 453-469.

Lim, D.I., 2001, Late Quaternary Stratigraphy and sedimentology of tidal-flat deposits, western coast of Korea. Unpublished Ph.D. dissertation, Seoul National University, Seoul, Korea, 303 p.

Lim, D.I. and Park, Y.A., 2003, Late Quaternary stratigraphy and evolution of a Korean tidal flat, Haenam Bay, southeastern Yellow Sea, Korea. Marine Geology, 193, 177-194.

Lim, D.I., Jung, H.S., Yoo, H.S., Seo, J.M., and Paeng, W.H., 2003, Late Pleistocene Unconformity in TidalFlat Deposit of Gyeonggi Bay, Western Coast of Korea. Journal of the Korean Earth Science Society, 24, 657667.

Liu, J.P., Milliman, J.D., Gao, S., and Cheng, P., 2004, Holoecene development of the Yellow River's subaqueous delta, north Yellow Sea. Marine Geology, 209, 45-67.

Nichol, S.L. and Murray-Wallace, C.V., 1992, Apartially preserved last interglacial estuarine fill: Narrawallee Inlet, New South Wales. Australian Journal of Earth Science, 39, 545-555.

Park, S.C. and Yoo, D.G., 1988, Depositional history of Quaternary sediments on the continental shelf off the southeastern coast of Korea (Korea Strait). Marine Geology, 79, 65-75.

Park, S.C., Jang, K.M., and Lee, S.D., 1990, Highresolution seismic study of Modern fine-grained deposits: Inner shelf off the southeastern coast of Korea. Geo-Marine Letters, 10, 145-149.

Park, Y.A., and Choi, K.S., 1998, Silty tidal rhythmites from the upper Pleistocene sedimentary sequence, western coast of Korea. Journal of the Korean Society of Oceanography, 33, 71-79.

Park, Y.A., Lim, D.I., Khim, B.K., Choi, J.Y., and Doh, S.J., 1998, Stratigraphy and subaerial exposure of late Quaternary tidal deposits in Haenam Bay, Korea (southeastern Yellow Sea). Estuarine, Coastal and Shelf Science, 47, 523-533.

Park, Y.A., Choi, K.S., Doh, S.J., and Oh, J.H., 1999, Late Quaternary (Late Pleistocene and Holocene) stratigraphy and unconformity in the Kimpo tidal deposits, Kyunggi Bay, West coast of Korea. Korean Journal of Quaternary Research, 13, 79-89.

Penland, S., Boyd, R., and Suter, J.R., 1988, The transgressive depositional systems of the Mississippi delta plain: a model for barrier shoreline and shelf sand development. Journal of Sedimentary Petrology, 58, 932-949.

Plint, A.G., 1988, Sharp-based shoreface sequences and offshore bars in the Cardium Formation of Alberta; their relationship to relative changes in sea level. In Wilgus, C.K., Hastings, B.S., Kendall, C.G.St.C., Posamentier, H.W., Ross, C.A., Van Wagoner, J.C. (eds.), Sea level changes: an integrated approach. SEPM (Society for Sedimentary Geology) Special Publication No. 42, SEPM, Tulsa, OK, USA, 357-370.

Plint, A.G. and Nummedal, D., 2000, The falling stage systems tract: recognition and importance in sequence 
stratigraphic analysis. In Hunt, D. and Gawthorpe, R.L. (eds.), Sedimentary response to forced regression. The Geological Society Special Publication No. 172, London, 1-17.

Posamentier, H.W., Allen, G.P., James, D.P., and Tesson, M., 1992, Forced regressions in a sequence stratigraphic framework: concepts, examples, and exploration significance. AAPG Bulletin 76, 1687-1709.

Qin, Y. and Zhao, S., 1991, Quaternary coastline changes in China. China Ocean Press, China, 192 p.

Shinn, Y.J., Chough, S.K., Kim, J.W., and Woo, J., 2007, Development of depositional systems in the southeastern Yellow Sea during the postglacial transgression. Marine Geology, 239, 59-82.

Skene, K.R., Raven, J.A., and Sprent, J.I., 1998, Cluster root development in Grevillea robusta (Proteaceae) I.
Xylem, pericycle, cortex and epidermal development in a determinate root. New Phytologist, 138, 725-732.

Suter, J.R., 2006, Facies models revisited: clastic shelves. In Posamentier, H.W. and Walker, R.G. (eds.), Facies models revisited. SEPM (Society for Sedimentary Geology) Special Publication No. 84, SEPM, Tulsa, OK, USA, 339-397.

Wang, P., Zhang, J., and Gao, J., 1985, A close-up view of lowered sea-level microfauna from the east China and Huanghai Seas in the Late Pleistocene. In Wang, P. (ed.), Marine micropaleontology of China. China Ocean Press, Beijing, 256-264.

Yim, W.W.-S., Ivanovich, M., and Yu, K.-F., 1990, Young age bias of radiocarbon dates in pre-Holocene marine deposits of Hong Kong and implications for Pleistocene stratigraphy. Geo-Marine Letters, 10, 165-172. 